\title{
Fair Value Accounting and Implications for the Auditing Profession: Historical Overview
}

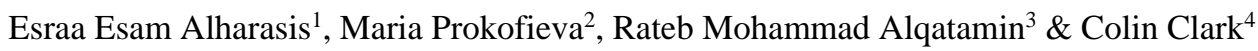 \\ ${ }^{1}$ Business School, AlharasisVictoria University, Australia \\ ${ }^{2}$ Business School, Victoria University, Australia \\ ${ }^{3}$ Department of Accounting, Tafila Technical University, Jordan \\ ${ }^{4}$ Victoria University, Australia \\ Correspondence: Esraa Esam Alharasis, Business School, AlharasisVictoria University, Australia.
}

Received: July 6, 2020

Accepted: August 10, 2020

Online Published: August 14, 2020

doi:10.5430/afr.v9n3p31

URL: https://doi.org/10.5430/afr.v9n3p31

\begin{abstract}
This paper explores the link between the introduction of fair value measurements (FVM) and the development of the Global Financial Crisis (GFC) in 2008-9. The paper aims to provide an historical analysis of the development of the Enron scandal with a focus on fair value accounting (FVA) and provides a narrative literature review of the subsequent economic downturn, its effect on the auditing profession and audit fees arrangements, implications for FVA, and response of global institutions and standard setters. It provides a theoretical explanation of the underlying antecedents using existing accounting theories. For each reviewed stream of research, the paper establishes the theoretical underpinning and discusses its application supported by the context. The content analysis using NVivo software was employed to analyse existing research and available published information. Based on the comprehensive literature review, the study arrives at two main findings. First, the paper concludes with the controversial use of FVM and establishes a direct connection between Enron's collapse, the GFC, and improper FVM practices. Secondly, the study identifies the current pricing strategy for audit as an industry response to the abuse of external audit arrangements regarding FVA. Supported by the literature review findings, the paper contributes to the audit research by providing deep insights into the connection between FVA practices, the GFC and development of the audit profession. The paper addresses the lack of foundational research in FVA and establishes a solid background for further studies on FVA and audit profession development in general.
\end{abstract}

Keywords: global financial crisis, FVA, enron scandal, audit pricing

\section{Introduction}

During the period between 2008 - 2009, the world economy was shattered by a critical economic downturn and the collapse of well-developed stock markets (Menicucci \& Paolucci, 2016). This situation threatened to destroy the global economy and led to insolvency of the mortgage market in August 2008 in the US and globally. FVA was questioned as being a central cause of the crisis (Barth \& Landsman, 2010; Laux \& Leuz, 2010). Since then the investigation of FVA practices and their influence on this severe crisis became a focus of attention of practitioners, authorities and standards setters.

FVA was enacted by International Accounting Standards Board (IASB) after releasing IAS 39 _ fair value option in June 2005, to increase consistency and comparability in fair values. FVA at that time was commonly used to measure financial assets and liabilities (IAS Plus, 2019). IAS 39 required entities to apply FVA following a three-level hierarchy (i.e. fair value level 1, level 2 and level 3 inputs) which was used in identifying the fair value for financial instruments. In the case of an inefficient or illiquid market, firms were required to use subjective valuation techniques to provide accurate assumptions regarding fair values especially those measured using level 3 (Freeman et al., 2017). Therefore, additional disclosure requirements were enacted by International Financial Reporting Standards (IFRS) to explain the valuation techniques and the inputs used to conduct those measurements (IAS Plus, 2019). Thus, FVA allowed extensive discretion into management evaluations which meant higher risk and complexity in preparing and auditing fair values (Khlif \& Achek, 2016; Watts, 2006). 
The GFC led to greater market volatility which endangered the reliability of FVM (Allen \& Carletti, 2008; Magnan, 2009). The risk became higher, particularly for level 2 and level 3 fair value inputs (Bratten et al., 2013) which resulted in increasing auditors' burden and eventually driving up audit prices (Xu et al., 2013). The financial crisis led to numerous abuses and FVA fraud practiced by managers to enhance their owners' confidence in the firms' financial performance (de Jager, 2014; Ryan, 2008). The only way to minimise the agency problem is to hire an external auditor who acts as a monitoring tool to send positive signals to stakeholders through providing assurance for the reliability of the firm's disclosed financial reports (Hodge \& Pronk, 2006). Therefore, auditors came under additional scrutiny to meet stakeholders' needs for high-quality financial reporting for making decisions (Alqatamin, 2018; Baker \& Owsen, 2002).

Following the eruption of the GFC, the IASB realised there was an urgent need to offer additional explanations on how to measure fair values of assets and liabilities, especially in the case of an inefficient market to improve the transparency of FVMs by offering additional disclosures to address measurement uncertainty (IFRS Foundation, 2020a). The joint effort between the IASB and the Financial Accounting Standards Board (FASB) with the recommendations of G20 organisers resulted in establishing the Fair Value Expert Advisory Panel in May 2008 which included regulators, auditors, and users of accounting information (IFRS Foundation, 2020a). They reviewed best practice regarding the valuation techniques and formulated guidelines for additional practices on valuation methods (IFRS Foundation, 2020b). Consequently, IFRS 13: Fair Value Measurement was established, and fair value hierarchy required disclosures about the three levels of fair value inputs (IAS Plus, 2020).

This paper aims to summarise the development of the GFC. It provides a comprehensive understanding of the contributions to Enron's collapse and explains the main lessons to be learnt. The current paper purposes to present the literature examining the causes of the GFC and the role of FVA in this crisis along with the important implications for the audit profession, and particularly audit pricing. This paper attempts to the answer the following questions:

1- To what extent fair value contributed to the economic downturn?

2- What are the major influences of this crisis on the audit profession (audit pricing)?

The current paper benefits researchers and academics as such a review provides further evidence on this neglected field in accounting knowledge. The current study argues that FVA and its consequences on the auditing landscape are a fertile ground for future research. According to current analyses of the area, many scholars (Abdullatif, 2016; Ball, 2016; Khlif \& Achek, 2016; Samaha \& Khlif, 2016) have suggested that future scholars should refine their emphasis on this neglected area at either a country or international level to inform standard setters and regulators about the real impacts of FVA on the audit profession.

For accounting bodies in countries that have not yet implemented FVA, such as in the Middle East, the current paper might help in highlighting the witnessed effects of this implementation on the auditing profession. Lessons can be generated based on nations experiences regarding the extent to which fair value effects audit practices and its major challenges faced by preparers and auditors. This paper contributes to what local audit firms need to do to get the required training and education following IFRS fair value adoption as required by International Federation of Accountants (IFAC) guidelines and International Standards on Auditing (ISA). Consequently, auditors need to be aware of any expected risks of fraud and misstatements in the published financial information prepared under fair value disclosure requirements. Therefore, this paper offers a starting point for developing accounting research on fair value phenomena and its major implications.

The existing literature on FVA is scarce especially related to auditing. This paper is the first of its kind to provide an historical explanation of this economic event, which had serious worldwide implications based on historical documents, as well as gathering empirical studies. NVivo software has been used to develop the final conclusions. The current paper extends the Haswell and Evans (2018) discussion on the development of the GFC, Enron scandal and the role of fair value by providing an updated discussion which reviews the more recent published work by accounting scholars and discusses the main implications of the economic and accounting developments on the audit profession, particularly audit pricing.

The paper not only reviews the empirical research findings and factual information, it also provides a theoretical explanation of the underlying antecedents using existing accounting theories. Such an overview ensures appreciation of the current economic landscape and the impact of future developments. The overall conclusions drawn from this paper are that the crisis was not because of one particular factor; however, it reflects the failure of the entire financial system in regard to evaluating the challenge connected to the lack of active markets and the rapid evolution of organised risks of mortgages. This was caused mainly by a real estate bubble which led to indefensible large values in 
2006, due to the valuation of real estate and subprime securities and the lending system. Thus, since the market crunch in 2007, fair value and its practices have been the subject of extensive debate. This criticism is due to using fair value to measure illiquid securities, and the basis of this argument is that the market process is faulty since the application of FVA caused economic booms, doubling values in banks' financial statements at the top of the cycle and diminishing them through using the same measure at the bottom. Thus, there was a great risk to the audit profession which resulted in higher audit prices. Major reforms were implemented to overcome the damage wrought by the crisis, and thus increased the workload of auditors and thus the audit prices due to the greater complexity of the audit process.

The remainder of this paper is organised as follows. Section 2 traces chronologically the development of the global financial crisis and the role of FVA. Section 3 presents the theoretical support on the association between the crisis and the application of FVA, and the influence of this relationship on the audit profession, particularly audit pricing. Section 4 presents a literature review. Section 5 provides a detailed discussion addressing the questions in the paper. Section. Section 6 summarises and concludes the paper.

\section{FVA and the Global Financial Collapse (Enron's Crisis): Historical Background}

In the 1990s, FVA was re-introduced into the US FASB and the IASB accounting standards. Subsequent to the stock market crash and worldwide financial collapse known as the Great Depression in 1930s, for almost more than 50 years FVA had rarely been implemented. The 1930s-economic collapse had been suspected of overstating assets because of FVA valuation techniques, which had been used unsystematically (Zeff, 2007). By the 1960s, scholars and practising economists (Burton, 1971; Chambers, 1966; Sterling, 1967, 1970) deemed possible the restoration of a much more "scientific" strategy for assets being constantly re-measured. Some such concepts were eventually deployed in the long-term as experimental "inflation accounting" systems (Haswell \& Evans, 2018). This is despite the rationale for which they were originally designed and did in fact encompass much more than adjustments to general inflation issues.

Although in a recent study, Whittington (2015) noted that in the 1990s economic inflation dropped away, other factors led to the re-introduction of practices such as the FVA model. The US scandal in the 1980s has been accused of the deliberate abuse of the historical cost model. What happened is that bankrupt institutions hid their financial failure on tradable securities through using the historical cost model of amortized cost. Financial failure was not reported and thus was ignored on the condition that these securities were still being held, yet according to Johnson et al. (1995) profits could be reported for securities rising values. For this reason, FVA in the early 1990s was put forward as a remedy, so that losses as well as profits could be accounted for in a timely and honest way. Regulators noted the rise of financial instruments and wanted a method with which to measure those financial assets that were being rapidly traded fairly (Heaton et al., 2010). The consequence of this was the FAS 115: Accounting for Certain Investments in Debt and Equity Securities (FASB, 1993).

Schultz and Hollister (2003) noted that following pressure by conservative banks, the standard only needed some investments, in other words, those proposed to be sold in the short-term and those prepared using fair value through the profit statement. There was no noticeable change in these requirements when they began in 1993 until after the GFC in 2008-2009. Other fair value standards, also comprising mixed forms of measurement, soon followed FAS 115, for example FAS 123: Accounting for Stock-Based Compensation (FASB, 1993), and FAS 133: Accounting for Derivative Instruments and Hedging Activities (FASB, 1998). The standards represented efforts to prepare fair values through the profit statement in specific scenarios. In 1998, IAS 39 was established by the IASB. At that time, IASB standards were referred to as International Accounting Standards (IAS). Subsequently, FAS 115 was equivalent to IAS 39: Financial Instruments: Recognition and Measurement, (IAS Plus 2019). In fact, IAS 39 and FAS 115 were similar in adopting a mixed approach (both fair value and historical cost models) (see Appendix A, Table 1).

Given that FVA started as a device that would control financial reporting, corporate managers were not long in misusing it for their own benefit and in such ways that regulators had not intended. FVA in the 1990s should be viewed in the context involving malfeasance issues that greatly affected the rest of accounting standards. The 1990s marked a decade of economic boom and resurgence, yet Western economies were tainted by an environment where 'fast and loose' corporate practices were increasingly accepted. Before long, economic and financial policy regulators found that the accounting rules were being manipulated by companies to book profits (Bolton et al., 2006; Coles et al., 2006). The response to these issues, as pointed out by Haswell and Langfield-Smith (2008) was that - and especially in the US -what emerged was an ever-burgeoning rise in how complex the accounting rules were becoming. Accounting standards had become documents that were hundreds of pages long, containing far too many guidelines on implementation, yet corporate managers were able to manipulate the standards' intentions for their own ends. Subsequently, regulators and corporations were engaged in much expensive litigation concerning alleged abuses and dereliction of duty. FVA eventually became part of this list of abuses, but it had not been immediately recognized as a 
serious issue. Despite regulators and standard setters being aware of other types of financial manipulations, they were not aware of, or they simply remained unresponsive to fair value fraud until the Enron collapse (Saunders et al., 2009).

When the GFC engulfed the world's economy in 2008, manipulated financial products caught the attention of many scholars and practitioners. Basically, management assumptions serve to initially evaluate products initially and to consider profits as the market rose. While, managers increasingly depended on overstated values for their companies so that they received bonuses, changes to companies' financial assumptions would not be considered as actual losses. Literature has now been published on this scenario, closely linked with an increase in trading in financial instruments' decline. According to this perspective, FVA is blamed as it led to the manipulation of financial assets' prices which resulted in a market bubble. This has been reported in several studies (Hackenbrack \& Knechel, 1997; Krippner, 2005; MacKenzie, 2006; Perry \& Nöelke, 2005; Perry \& Nölke, 2006).

Enron was the first major company to become bankrupt during the "dot.com" crisis in the 2000s. While in the 1990s Enron was operating as an energy producer, towards the end of this period it held few physical assets and operated as a financing company. As discussed in the academic literature, the Enron collapse was caused by its considerable use of special purpose entities (SPEs) and complex contracts, and the strong connection with auditors (by Abdel-Khalik, 2002; Revsine, 2002). FVMs techniques were used unsystematically by Enron to manipulate its assets' values. Since that time, and especially the watershed year of 2008 , there has been considerable literature concerning companies' fraud and misstatement of mark-to-model measurements. According to Partnoy (2003), by the end of the 1990s Enron had unfairly reported billions of dollars in unreal revenues. A subsequent increase in management salaries and bonuses based on these profits was noticed. Specifically, in 1998, 1999, 2000 the top 200 staff got \$193 million, \$402 million, and $\$ 1.4$ billion, respectively. These amounts were being paid just prior to the company's collapse (McLean \& Elkind, 2013), which heralded the start of an avalanche of companies failing spectacularly, for example WorldCom, Sunbeam, Global Crossing, Tyco, Qwest, Parmalat, etc... (Clarke, 2007). Some analyses (Ball \& Brown, 1968; Kothari, 2001) contend that in the wake of these corporate collapses, accounting numbers no longer "fool" the market.

Despite the many years of accepting Enron's financial reports at face value, financial analysts, government authorities, policymakers and investors all failed to recognize the unfolding disaster. It is possible that these market downturns, display a serious challenge. Little attention was received from the academic literature before Benston's article in 2006. Flegm (2005) contends that the central cause of accounting fraud is the abuse of fair valued derivatives carried out by corporations such as Enron, Qwest, Global Crossing and Parmalat, and briefly illustrates one of Enron's mismeasurements. In November 2006, Haldeman (2006) offered a detailed investigation of Enron's FVA. These articles seem to launch the start of a detailed examination of issues related to FVA in the accounting literature. These authors assert the fact that the FVA problems of Enron were not widely examined at that time. Several questions about Enron remain unanswered, such as how did the FASB escape criticism for what happened at Enron? Being able to recognise FVA should really be about the extent of responsibility for the collapse held by regulators, politicians, and other stakeholders at that time. Answers to such questions would assist in explaining how the standard setters and regulators response resulted in practices that later became problematic during the GFC. In fact, the GFC is the Second Fair Value Crisis after the Enron debacle (Gwilliam \& Jackson, 2008).

As a response of the credit crisis in 2008, the European Union officially asked the International Auditing and Assurance Standards Board (IAASB) to return to historical cost accounting instead of FVA through making changes in its IFRS. As a result, banks could reclassify securities held for trading (Haswell \& Evans, 2018). On 13 October 2008, the required amendment was made, namely "Amendment to IAS 39 for reclassifications of financial assets" (IAS Plus, 2019). The modified classification of securities as addressed by IAS 39 was for: held-for-trading securities, available-for-sale securities, and held-to-maturity securities (amortized cost) (IAS Plus, 2019).

The outcomes of these modifications are revealing. For example, the 2008 IASB's amendments permitted the European banks to raise their profits to about $\$ 29$ billion in the same year (Pozen, 2009). Furthermore, banks' managements and boards of directors stated that when they have the option to not apply FVA for the securities that traded in reduced liquidity markets they do so and use historical cost accounting instead. This consequently led to the provision of financial statements compiled and audited under the modified financial reporting standards. Such statements fairly reflect the financial position of the published business entity (Power, 2010).

\section{Theoretical Underpinnings}

In relation to theory, much of the prior literature discussed in this paper employed agency and/or signalling and/or stakeholder theories to explain the FVA concept and its relation to the GFC and audit profession development (Badia et al., 2017; Bell et al., 2015; Ruddock et al., 2006; Sangchan et al., 2020; Watts, 2003). Scholars generally agree that corporates seek to get an assurance from third parties that their FVMs are reliable. Information related to FVA may 
vary due to the limited market discipline over such complex estimates, and no amount of reliable assurance can be obtained perfectly. Correspondingly, external auditors as an independent third party are expected to provide a reliable verification of firms' FVM (see Figure 1). Agency and signalling theories are widely used to explain the choice of accounting methods (Khlif \& Achek, 2016; Samaha \& Khlif, 2016). Furthermore, stakeholder theory expands on agency theory by emphasizing the need to supervise all groups of stakeholders, with high quality financial information to responsibly allocate resources. Detailed discussion on the connection of these theories is provided below in the literature review and discussion sections.

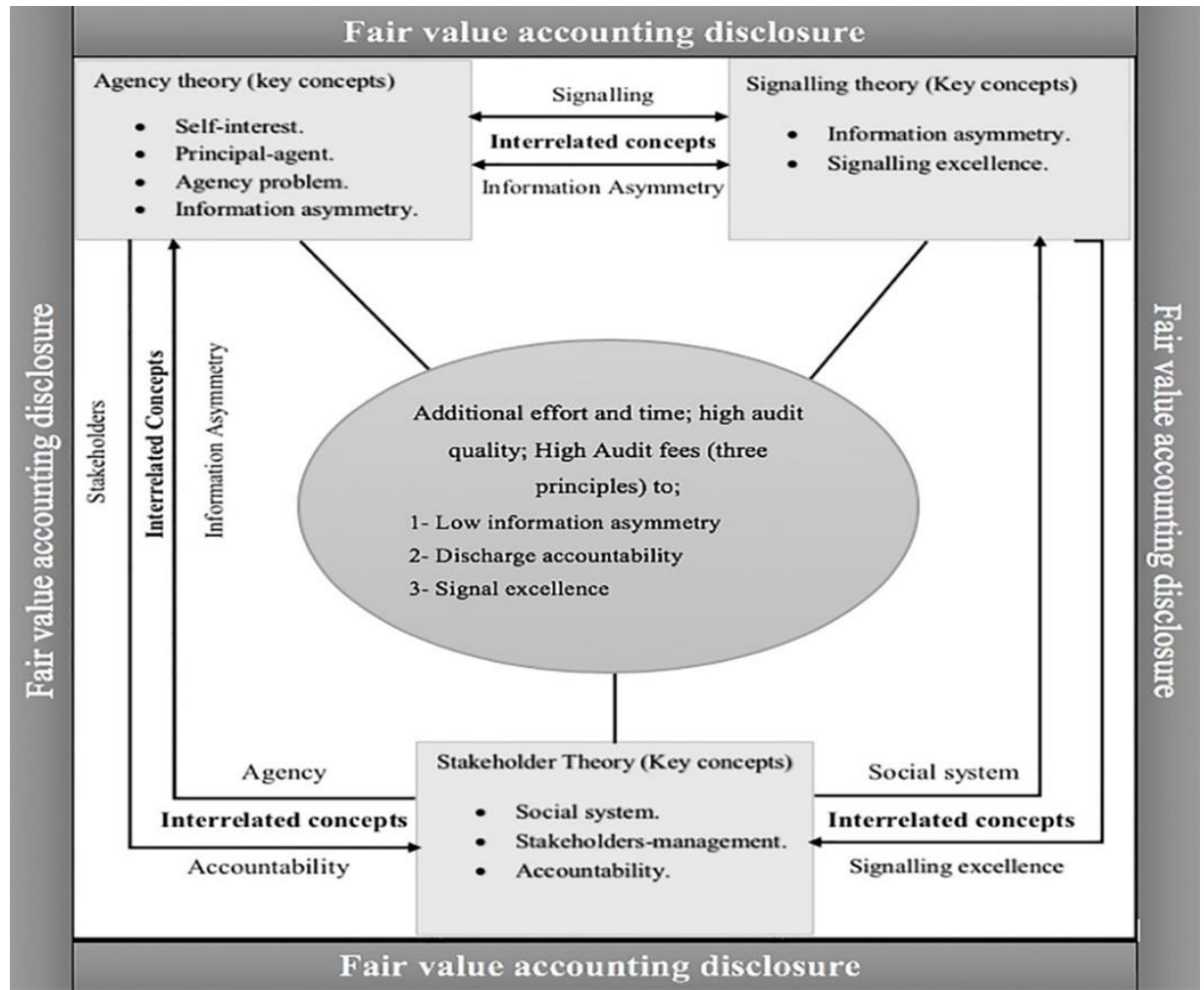

Figure 1. FVA and Audit Pricing: theoretical framework (adapted from An et al., 2011)

\section{Literature Review}

In 2007 due to the agency conflict, financial instruments were valued at fair value in the illiquid market and sold below the fundamental value; its future cash flow or its amount that would be received when it is sold in order to meet the authority's capital needs (Haswell \& Evans, 2018). As this situation led to increased volatility in market prices, it caused uncertainty in investors and undermined confidence in market values. Thus, decreases in prices and firms' asset values resulted, and further increased market illiquidity and threatened financial stability. Moreover, FVA was blamed for causing price bubbles in accounting information (Foster \& Shastri, 2010; Penman, 2007) which exacerbated the GFC (Trussel \& Rose, 2009). From this point of view, it is difficult to ignore the major role of FVA in creating the crisis. Two controversial perspectives regarding the alleged role of FVA in the GFC are discussed briefly as follows.

\subsection{The GFC and the Role of FVA: Theoretical Support}

The theoretical stream of FVA and GFC literature mainly focusses on providing an analytical conceptual evaluation of pro-cyclicality of FVA and investigating where FVA could possibly lead to increased volatility and negatively affect business cycles during the crisis period. Based on agency theory, several scholars (Carosio, 2008; Laux \& Leuz, 2009, 2010; Magnan, 2009; Menicucci \& Paolucci, 2016) have agreed that the pro-cyclical impact of FVA led to creating incentives for managers to mislead investors due to the extensive use of unrealised gains especially for financial instruments. Therefore, some scholars like Magnan (2009) reported that FVMs include valuations such as pro-cyclicality because they are subject to economic adjustments. Furthermore, a considerable number of scholars have responded to the debate regarding the relationship between FVA and the GFC (Bout et al., 2010; Bowen et al., 2010). They empirically examined the possible pro-cyclical impacts of FVA during the GFC period. Bout et al. (2010) investigated the potential pro-cyclicality of FVA and suggested that it indicates only a small pro-cyclical effect on financial institutions' financial statements. However, Barth and Landsman (1995) found evidence that using 
mixed-measurement accounting systems might, in turn, have led to severe negative growth and have a pro-cyclical impact, ultimately leading to increased volatility in earnings by using FVA rather than historical cost accounting. A detailed discussion on these two controversial views follows below.

\subsubsection{The Proponents of FVA and the GFC}

This group of scholars argued that FVA played no major role in the GFC. For instance, André et al. (2009) did a comprehensive analysis of the responsibility of FVA during the crisis and agreed with the concept of "shoot the messenger". Barth and Landsman (2010) examined the contribution of reporting fair values during the crisis period. They found that FVA made little or no contribution to the credit crisis. Barth and Landsman (2010) agree with Ryan (2008), Wallace (2008), Pozen (2009), and Laux and Leuz (2010) that the negative outcome of the crisis could have been curtailed, if FVA had been employed earlier. Barth and Landsman (2010) stated that the role of FVA in intensifying the crisis is still unproven because FVM can be relevant when banks' assets are valued using FVA or for which fair value is employed to determine impairment. Furthermore, Laux and Leuz (2010) and Shaffer (2010) offer empirical evidence supporting the conclusion of Barth and Landsman (2010). According to Laux and Leuz (2010), there is little evidence that FVA results in extensive write-downs of a bank's assets. In this respect, Novoa et al. (2009) asserted that FVA is the best measure of the condition of financial firms despite the concerns about pro-cyclicality and measurement challenges.

Another school of thought found evidence in favour of FVA against its claimed pro-cyclicality. Badertscher et al. (2011) and Shaffer (2010) found no evidence regarding pro-cyclical behaviour following the adoption of FVA. Further, they reported that the effect of unrealized fair value write-downs on regulative capital has been found to be insignificant as well as there is no evidence of equivalent selling behaviour indicating pro-cyclical effects. Shaffer (2010) argued that FVA did not cause the crisis. Based on Shaffer's (2010) study, there is no support to claim that FVA motivates banks to sell their assets at distressed prices resulting in a pro-cyclical effect, accelerating the decline in investment assets prices. Rummell (2008), moreover, underlined that FVA was just a messenger which provided information on what had really happened. In that sense, Procházka (2011) and Bonaci et al. (2010) investigated whether FVA had played a messenger role or a contributor role to the financial turmoil. They concluded that fair value implementation was not responsible for the crisis and there is no solid evidence for this claim against fair value. Other studies (Brinza, 2011; Plantin \& Tirole, 2018; Veron, 2008) contended that some weaknesses caused by FVA cannot be neglected, whereas there was no evidence of potential pro-cyclicality.

Some studies (e.g. Devalle, 2012; Graham et al., 2000) point out that the state of the economy affects value relevance. Devalle (2012) documents that the comprehensive income statement provides more value relevance than the net income provided in the income statement. This conclusion means that the financial recession is positively associated with value relevance. Graham et al., (2000) stated that in the early part of the GFC the value relevance of fair-valued financial assets and liabilities is known compared to its value in a normal economic period (Song, 2015). Veron (2008) stated that FVM is not a perfect accounting system; however, it provides more value relevance compared to other accounting measurement alternatives.

\subsubsection{The Opponents of FVA and the GFC}

Another group of scholars asserted that FVA has motivated the crisis. They argued that financial reporting based on fair values has quickened the crisis and substantially extended its effects. Regarding fair value's pro-cyclical effects, Carosio (2008) stated that FVA increases income volatility and thus adversely affects economic stability, and damages investors' confidence in published accounting information. However, other evidence (see Matherat, 2008; Plantin et al., 2008) argued that using FVA as a measurement tool to measure financial instruments has its unanticipated outcomes, such as magnifying economic cycles, since FVA could communicate further volatility into financial reports and markets as a consequence. In general, it can be said that fair value information is largely volatile and easily subject to market prices. So, it can play an essential role in misleading investors' understanding of what is being published during market bubble periods. In this respect, Wallison (2008) and Whalen (2008) argue that some financial crises were caused by the finance industry stakeholders, and it can be argued that the earliest usage of FVA to measure financial instruments by banks is the first contributor to extreme credit expansion. Wallison (2008) noticed that FVA has been the primary reason for instability among financial firms and the US's crisis. The author also stated that FVA is strongly pro-cyclical and thus calls for an amended version of FVA. Magnan (2009) contended that FVA led to the crisis and played a principle role in disconnecting financial reporting from market reality. Further, the researcher added that FVA may have participated in expanding the failure among financial firms (Plantin et al., 2008; Wallison, 2008) suggesting that FVA accelerated the financial crisis. Allen and Carletti (2008) emphasized that FVA may have led to excessive bank bankruptcies and thus, manipulated stock prices in the case of illiquid markets. 
Some scholars criticise FVA and claim that FVA was the main cause of the GFC and the ensuing credit difficulties (Barr, 2012; Cathey et al., 2012). There is only little evidence in the fair value literature contending that the implementation of fair value was the cause of recession (Laux \& Leuz, 2010). In this respect, Song et al., (2010) asserted there was evidence for level 1 and level 2 fair-valued assets having higher value relevance than level 3 fair-valued assets. They also find that the values of financial assets at market value are lower than FVA. Consequently, they added that fair value did not depress assets' values, so did not make any contribution to the recession.

After the adoption of FAS 157 in 2006, just a short time before the GFC, examinations were conducted, using a relatively small data sample, of the value relevance of the three levels of FVA (Goh et al., 2015; Song et al., 2010). These studies examined the GFC period rather than providing any comparisons between the GFC with normal economic situation periods. Pozen (2009) stated that 'mark-to-market' accounting was the major cause of U.S. financial system distortion in 2008. This is due to misinterpreting FVMs to the interested parties (i.e. investors). A common criticism of FVM is that fair valuation in an insufficient market recorded less reliable values due to the marked-to-model rather than the marked-to-market one (Pozen, 2009). Interestingly, Kolev (2008) and Song et al. (2010) stated that during the GFC, investors handled this reduced reliability through discounting FVM information accordingly. Mala and Chand (2012) investigated the consequences of the GFC for banks' financial reporting. The scholars also explored whether the trend towards IFRS convergence is hampered by major issues and problems in the wake of IFRS 7: financial instruments. The research concludes that the GFC necessitated the convergence of the IAS. As a result, IFRS 7 put IASB under additional pressure to put into action appropriate mechanisms to improve the disclosure requirements following the GFC.

All in all, according to Menicucci and Paolucci (2016), accounting literature on the role of FVA within the GFC is limited and this area in accounting has not been examined extensively. They also identified a gap in research to empirically confirm that FVA was a trigger for the credit crisis. Menicucci and Paolucci (2016) confirmed prior findings of financial reporting practices; especially, exploitation of FVMs as a measurement technique for recording and reporting financial instruments in banks' financial statements. Therefore, FVA has been a subject of extensive debate which extended to blaming FVA as the main contributor of the GFC. This debate on FVA is due to the suspected pro-cyclicality impact of fair values on financial statements. Consistently, some commentators found evidence that FVA has been exposed to severe criticism despite its alleged advantages. On the other hand, some supporters of fair value stated that using market prices to prepare financial reports will benefit investors since such reports deliver more relevant financial information on the firm's real financial performance. Additional evidence by future researchers on this topic is still required.

\subsection{The Global Financial Crisis and Audit Fees: Theoretical Support}

Economic downturn periods have led to increased firm related risks such as insolvency thereby requiring high-quality audit services (Holm \& Zaman, 2012) and the associated time, effort and fees charged (Alexeyeva \& Svanström, 2015). The first initiative to enhance audit quality following the GFC was released in 2008 in the UK by the Financial Reporting Council (FRC). The FRC issued an "Audit Quality Framework" to improve the trustworthiness of auditing practices and institutions, with regulations enacted by independent bodies instead of following self-regulation. Holm and Zaman (2012) investigated the effect of this initiative and found this framework did not cover the interests of various stakeholders and may have threatened the commercial and competitive situation of audit firms. Similarly, Xu et al. (2013) conducted a study in Australia concluding that during the period between 2008-2009 auditors were subject to issuing going-concern opinions compared to the years 2005-2007. The researchers suggested that during the GFC, the risk associated with the probability of issuing an incorrect audit opinion is high due to the higher legal risks and reputation loss especially because of the increased regulatory pressure experienced during the credit crisis period. According to Chen et al. (2019), prior studies on the audit risk model were carefully reviewed by scholars who confirmed there is a significant association between the primary factors of this model: inherent, control and detection risk. Based on Cahan and Sun (2015), Cahan and Zhang (2006) and Elder et al. (2009), auditors' perceptions about audit risk are closely associated with changes in both inherent risk and control risk and thus ultimately, affect their performance in reducing detection risk (Kikhia, 2015).

Following the financial failure that led to catastrophic global downturns, attention to the development of ISA increased dramatically. This is due to the concerns about the quality of financial statements and auditing standards (Boolaky \& Soobaroyen, 2017). Financial statement frauds caused by large corporations such as Xerox, Enron, WorldCom, and Tyco, resulted in the demand for better governance, audit efficiency, integrity, and credibility in financial reporting (Wells, 2005). The severity of the GFC questioned the role of auditors since most financial firms got an unqualified audit opinion which ultimately led to scandal and/or collapse (Haswell \& Evans, 2018). This situation necessitates 
further revising the role of auditing in contemporary society, such as investigating whether auditors lack the necessary experience, expertise, independence or motivation to provide a true and fair judgement of firms' financial affairs (Humphrey et al., 2009; Sikka, 2009). It is argued by many authors that such standards are useful for the development of an efficient and effective global economy by delivering relevant and reliable financial information to investors and capital markets (Archambault \& Archambault, 2009; Leuz, 2010; Zeghal \& Mhedhbi, 2006).

In the last two decades, due to a significant increase in the number of complex multinational companies, the internationalisation of the auditing profession has been remarkable, alongside the auditing standards-setting and governing processes. The ISAs are established by IFAC through the IAASB, in conjunction with services provided by public supervising bodies in various global jurisdictions (Simnett et al., 2016). The US's auditors' Statements on Auditing Standards (SAS) are established by the Auditing Standards Board of the American Institute of Certified Public Accountants (AICPA) in the case of auditing non-public firms. However, they employ the Public Company Accounting Oversight Board's (PCAOB) Auditing Standards (AS) when auditing public firms. Generally, ISAs are principle-based standards, whereas SAS and AS are rules-based standards.

Existing research argued that during the GFC, managers tended to manipulate financial information to hide their poor financial performance. Theoretically, this behaviour could lead to more client risk requiring additional audit tests and procedures, thereby expensive audit prices are anticipated to be charged to compensate auditors' efforts. In this sense, some researchers have confirmed that audit fees are positively associated with the GFC in several countries, such as the US (Desai et al., 2016; Doogar et al., 2015; Krishnan \& Zhang, 2014), Australia (Xu et al., 2013), the UK (Holm \& Zaman, 2012), China (Zhang \& Huang, 2013), Sweden (Alexeyeva \& Svanström, 2015), and Slovenia (Groff et al., 2017).

Studies that use non-US markets' data tend to make comparisons between the crisis period and pre-crisis period providing evidence for audit risk premium during the financial crisis. A study conducted by Chen et al. (2019) using a sample of 5636 firms operating in US markets for the years 2006-2011, examined the effect of the GFC on audit fees and the association between audit fees and the financial restatements. Furthermore, the study examined the extent to which the association between audit fees and restatements grew during the financial crisis. Due to the increase in the macro-systemic risks, audit prices significantly increased. In addition, a significant positive association has been found between audit fees and restatements where restatement has been used as a proxy showing the poor financial reporting and auditing quality. Zhang and Huang (2013) investigate the increased risk of audit fees using a sample from Chinese companies during the year 2008. The study concludes that audit firms charge higher audit fees because of the increased risk associated with the GFC. A study conducted by Alexeyeva and Svanström (2015) aimed to examine the changes in audit and non-audit fees during the GFC using data from 195 firms operating in Sweden for the period 2006-2011. It concluded that audit fees were significant during the GFC and this increase continued into the post-crisis periods since auditors' emphasis is more on firm's leverage and whether they report losses. Groff et al. (2017), moreover, examined the effect of the GFC on audit fees in Slovenia. Furthermore, Sonu et al. (2017) provide empirical evidence for the impact of the GFC on audit fees in Korea. Their study concludes that during the crisis period, audit fees significantly dropped, and auditors respond differently to small clients, and thus they attempt to reduce their fees so as to share economic pain with those clients.

In general, prior literature documented mixed results concerning the effects of the GFC on audit pricing. For example, Krishnan and Zhang (2014) focused on the US banking industry and concluded that a considerable number of banks reported audit fee discounts, whereas others (Alexeyeva \& Svanström, 2015; Zhang and Huang, 2013) investigated non-US firms and concluded that audit fees rose following the GFC. In the same vein, Sikka (2009) provides cross country evidence on the association between the GFC and audit fees. The researcher reports that the financially distressed banks paid expensive audit prices to external auditors during the crisis period. In short, the GFC put external auditors under pressure to ensure the disclosed financial information of firms was correct, to avoid unexpected future problems. Recovery plans stressed the external auditor's role in providing fair opinion regarding the reasonability of a firm's financial statements. Others provide a different perspective on how fair value is used during the GFC, such as auditing aspects highly linked with the role of FVA (de Jager, 2014; McCreevy, 2008; Roberts \& Jones, 2009). Conversely, some scholars have reported the opposite. A negative effect of the GFC on audit fees has been found by some scholars in different contexts, such as the US (Krishnan \& Zhang, 2014) and South Korea (Sonu et al., 2017). These studies stated that the reason for this negative relationship between the GFC on audit fees is due to the lower requirements of audit services by audit clients during the GFC.

All in all, mixed results are documented in the current literature about the effect of the GFC on audit pricing. The variations in these studies findings is due to the difference in the severity of the GFC's consequence from country to 
country. Some economies were greatly affected compared to other countries, so it is difficult to generalise the results observed in a single market to all markets. Furthermore, some researchers have examined the impact of macroeconomic factors on the auditing profession and looked at shorter time periods, so they may be very biased to generalise findings regarding the effect of the GFC on audit pricing.

\section{Discussion}

\subsection{Fair Value Contribution to the GFC}

During the GFC in 2008, global accounting institutions were saddled with the FVA ideological baggage. The industry response to criticism of FVA was to firstly, refute that mark-to-market FVA was challenging when linked with inactive markets; and secondly, when there are no options, return to the mark-to-model of FVA. It is still probably the case that modern standard setters deny these issues, just as back in 2001 when problems concerning Enron and FVA were ignored or brushed aside. Following the Enron collapse, the US accounting system lost some of its credibility and prestige. As argued by prior scholars, a major problem with IFRS is that the standards are full of voluminous implementation guidelines (Nobes, 2005).

Following the eruption of the GFC, more concerns emerged about FVA (Mala \& Chand, 2012). The IASB and FASB spent much effort in improving the financial reporting quality and requirements and limit the differences. This provides one set of reporting disclosure requirements to be more harmonised, consistent and more robust. Consequently, IFRS has become a single language of reporting framework to have better and symmetrical reporting (Uzma, 2016) (see Figure 2 below).

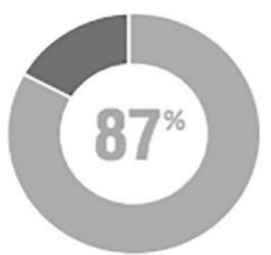

144 of 166

profiled jurisdictions require the use of IFRS Standards

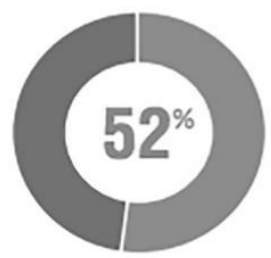

86 of 166

profiled jurisdictions require or permit the use of the IFRS for $S M E S^{*}$ Standard

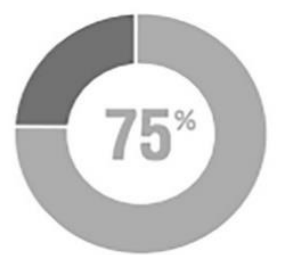

15 of 20

G20 economies require the use of IFRS Standards

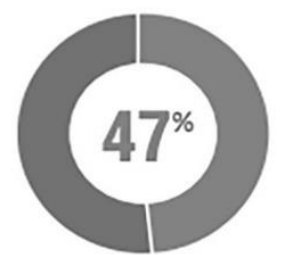

35 tn of 76 tn

The GDP of jurisdictions that require the use of IFRS Standards is $\$ 35$ trillion of the total world's $\$ 76$ trillion

Figure 2. IFRS application status (IFRS Foundation, 2020b)

According to Duh et al. (2012), most of the GFC related problems were caused by the increased complexity level and ambiguity of financial instruments following the adoption of IAS 39. Based on literature discussed above (Allen \& Carletti, 2008; Matherat, 2008; Plantin et al., 2008; Wallison, 2008; Whalen, 2008), using the mark-to-market accounting practice resulted in expanding the effect of the credit crisis through increasing the level of earnings volatility. This was due to recognising losses of assets whose values had fallen dramatically.

During the GFC, the accounting debate on FVA became highly political when economic changes had a direct effect on investors' and managers' behaviour. As a result, significant discussions by lobbyists, banking associations and governments emerged and became part of the "fair value political debate" (Bischof et al., 2011). Although, the credit crisis and other recent global incidents have increased the on-going debate over the FVA model. Global accounting institutions and regulatory authorities' rules have continued to include FVA projects. The effort in updating IFRS 13 (IASB, 2011) and the continuous effort and emphasis of IFRS over the development of FVA with important related issues of FVM in the absence of an active market has not ended the debate. The requirements regarding 'fair value hierarchy' multiplied the subjectivity levels of fair value estimates which also continues to raise concerns. 
According to Haswell and Evans (2018), FVA is a constellation of methods that revise the values periodically, particularly financial assets, such as swaps, option and tradeable accounts. The methods are divided into two versions of FVA "mark-to-market" and "mark-to-model". The "mark-to-market" technique, is based on verifiable market prices of the moment as a reference point for values adjustments, such as quoted market prices. Conversely, the "mark-to-model" technique is based on management assumptions to estimate and revise values of assets based on valuation techniques regarding the asset's future conditions (see Figure 3 below). The latter technique leads to a larger information asymmetry problem caused by the separation between the agent and principal or between principal and principal, in some cases. Studies (American Banking Association, 2008; Plantin et al., 2008) claimed that FVA contributed to the GFC by forcing unrealistic asset impairments. However, the advocates of FVA stated that the main source of the crisis was banks' poor lending practices, while FVA did nothing to make the crisis (Laux \& Leuz, 2009).

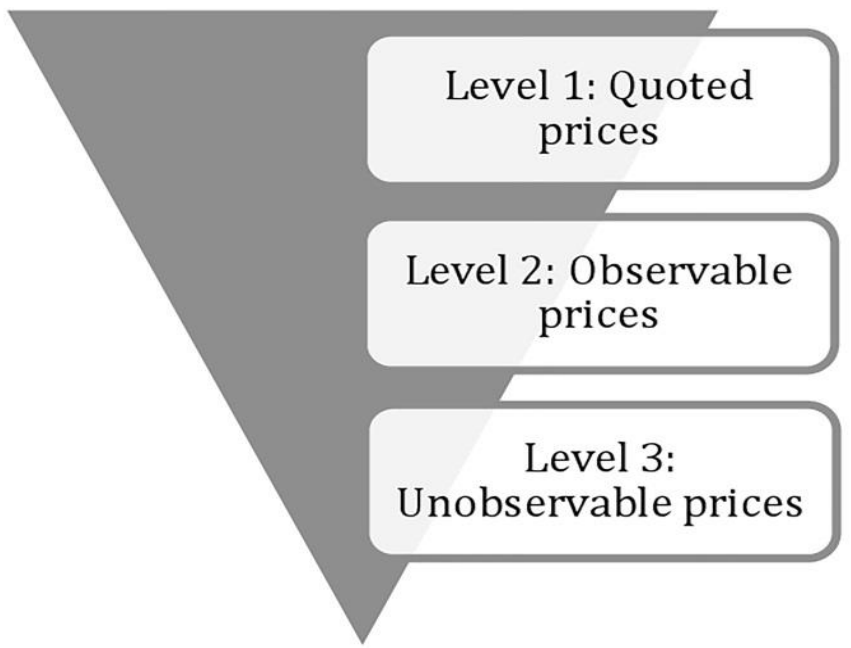

Figure 3. Fair value hierarchy (IAS Plus, 2019)

The main criticism of FVA was sparked by enabling the wide usage of the "mark-to-model" version of FVA by managers which ultimately led to financial restatement and manipulation to hide assets' losses (Gläser \& Laudel, 2013). According to Benston (2006), Enron used fair value through level 3 and level 2 estimates extensively for its internal and external reporting. Enron extensively used level 3 inputs for energy contracts first, then for trading activities and undertaking merchant investments. The extensive usage of these fair values is done to compensate senior managers. With Arthur Andersen as auditors, Enron's accountants employed accounting mechanisms to report cash flow from operations other than financing to hide fair value overstatement and managers' projects losses. Benston (2006) concludes that the main cause of Enron's demise is FVA.

As mentioned in the previous section, existing research indicated fair value as the main cause of the GFC (Allen \& Carletti, 2008; Carosio, 2008; Magnan, 2009; Matherat, 2008; Plantin et al., 2008; Wallison, 2008; Whalen, 2008 etc.). Amel-Zadeh and Meeks's (2015) research analytically found evidence that US-banks with strong obligatory regulations lack differences in regulatory risk; thus, they do not exhibit procyclical leverage in contrast to banks with weak obligatory regulations. On the other hand, some scholars defend FVA and state that it was the messenger of the credit crunch rather than the cause (Barth \& Landsman, 2010; Bonaci et al., 2010 ; Pozen, 2009; Procházka, 2011; Ryan, 2008; Wallace, 2008 etc...). For example, Veron (2008) proposed that FVM was not the perfect accounting system; however, it provided more value relevant financial information compared to other accounting measurement alternatives. This group of accounting scholars investigated the way the GFC emerged, and they present evidence that FVM played only a minor role in the GFC (Laux, 2012; Laux \& Leuz, 2009, 2010).

Generally, the role of FVA within the GFC is still not proved as there is still not sufficient research undertaken on this area (Haswell \& Evans, 2018). Thus, fair value's contribution to the GFC remains uncertain, especially its presumed pro-cyclical effect in exacerbating the crisis. Furthermore, Menicucci and Paolucci (2016) conclude that although extreme criticisms against FVA and its role in the GFC are documented in the accounting literature, it is the best available alternative accounting measurement for financial reporting. 


\subsection{The Major Influences of the GFC on the Audit Profession and the Role of FVA}

Based on the literature review in the previous section, it was argued by Allen and Carletti (2008) and Magnan (2009) that the GFC led to greater market volatility which endangered the reliability of FVMs. The risk became higher, particularly for level 2 and level 3 fair value inputs (Bratten et al., 2013) which resulted in increasing the auditors' burden and eventually driving audit prices up (Xu et al., 2013). The GFC brought in its wake many abuses including FVA fraud practiced by managers to enhance their owners' confidence in their firms' financial performance (de Jager, 2014; Ryan, 2008). Consequently, several reforms were implemented to mitigate the damage wrought by the crisis (Alexeyeva \& Svanström, 2015; Abdullatif, 2016). Some reforms concerned the audit profession regarding fair value estimates and thus increased auditors' efforts, meaning an increase in audit fees. The previous mentioned literature has found empirical evidence that the adoption of FVA was one of the GFC causes due to the increased usage of uncertain estimates prepared by company managers. This complexity and risk resulted in higher audit prices.

Following the increased prevalence of FVA in accounting standards, specific attention was given to FVA issues. This is due to the important debate regarding the greater use of the valuation techniques underlying certain fair values which are complex and different from one industry to another and its reliance on unobservable inputs (Sangchan et al., 2020). As a result, using FVA to prepare firms' assets and liabilities estimates needs a third party to ensure the reliability and credibility of the fair values prepared by managers (Griffith et al., 2015; Lachmann et al., 2015). Auditors, in this case, should act as a monitoring tool to assist shareholders in making decisions by minimising the problem of asymmetric information caused by the agency conflict (Mattingly et al., 2009; Sangchan et al., 2020). The ongoing debate regarding the major role of FVA on the crisis had implications for accounting practices particularly the auditing profession. The embarrassing situation that large audit firms had been in, has turned the attention to the apparent failure of these firms to identify banks' financial failure (Hopwood, 2009). Subsequently, the role, significance and independence of external auditors have been questioned because most failed institutions had got unqualified opinions (Haswell \& Evans, 2018). As a response to the GFC, the issue of auditing fair value estimates was the main issue for the auditing profession (Dixon \& Frolova, 2013; IAASB, 2008; Smith-Lacroix et al., 2012; Woods et al., 2009).

Auditing fair value estimates was first required by IAASB in February 2008 through the ISA 540: Auditing Accounting Estimates, Including FVA Estimates, and Related Disclosures ISA 540 (IAASB, 2009). ISA 540 underlines the typical audit approach for auditing accounting estimates, including fair value estimates. ISA 540 replaced ISA 545: Auditing FVMs and disclosures, which only covered auditing issues related to FVA (IAASB, 2004). Auditors under this IAS 540 are required to assess the material misstatement linked to fair value estimates. Therefore, auditors were required to obtain a comprehensive understanding of how managers arrive at the prepared estimates and the data that they are based on to prepare these estimates (IAASB, 2009, paragraph 29-32). To do this, auditors are required to assess internal controls, valuation techniques used, management's use of specialisation and experience, and assumptions leading to the estimate. Further, auditors were required to respond to any identified risks by evaluating the relevant transactions and events after the balance date. They must also assess how management made its estimates and the data they were based on, look at the reasonableness of measurement tools used by managers, test the efficiency and the effectiveness of internal controls and finally develop their own estimates to compare them with those prepared by managers (IAASB, 2009, paragraph 23). Auditing fair value estimates with level 3 presented more challenges, and such estimates required specific attention from auditors who in this case, needed to develop technical knowledge in fair valuation techniques and relevant audit procedures. Such estimates, moreover, placed significant demands on auditors to enhance their professional scepticism, judgement, negotiation skills and moral bravery (Benston, 2006; Kumarasiri \& Fisher, 2011; Sangchan et al., 2020).

Since the financial crisis unfolded in 2008, FVMs have become a crucial area of accounting and the emphasis on the need for fair value disclosure (Xu et al., 2013). FVMs uncertainty creates an urgent need to increase the transparency of corporate information (Benston, 2006; Laux \& Leuz, 2009; Penman, 2007; Sangchan et al., 2020; Yao et al., 2018). A large debate has occurred among accounting scholars (see de Jager, 2014; Laux \& Leuz, 2009) stressing the possible role of FVA in the GFC. As a consequence of this business turmoil, the demand for high quality financial reports increased dramatically, since financial reports are the primary communication means that can be used to bridge the gap between managers and stakeholders (Amel-Zadeh \& Meeks, 2015). In addition, a verification of the reliability of such reports is increased also to improve the confidence of the capital markets and increase the investors' trust in such information (Shaw, 2003). For the financial information to be trustworthy it should be comprehensive, transparent and timely to minimize the asymmetric information problem originating from agency conflict (Healy \& Palepu, 2001). Thus, highly qualified supervision of managers' practices and a reduced agency problem translated by high audit fees are all factors which lead to superior financial disclosure (Gaynor et al., 2016). As a result, a fresh concern about FVM emerged in the aftermath of the 2008-2009 financial crisis due to the extensive use of managerial assumptions to 
prepare fair values especially in the case of absent active markets (Alexeyeva \& Svanström, 2015; Demartini \& Trucco, 2017; Groff et al., 2017).

Generally, some scholars in the literature criticized FVA as the main cause of the GFC due to the increasing use of management assumptions to determine the fair values of assets and liabilities (Laux \& Leuz, 2010). Based on agency theory, the adoption of FVA has led to material misstatements, and managers' fraud and abuse of their power, as well as misleading shareholders and serving their personal interests (Menicucci \& Paolucci, 2016). This combines with the lack of a specific guideline and sufficient legislation related to measuring and auditing such complex estimates. In addition to the lack of active markets, the lack of skilled and knowledgeable preparers and auditors and the weakness or non-existence of corporate governance mechanisms are the situations in most countries (Nguyen, 2019). This situation has also resulted in the biggest auditing failure in world economic history which led to considerable reforms to overcome the severe effect of the crisis with relation to the application of FVA. Auditors, therefore, were required by regulatory authorities to spend additional time and effort to ensure the quality of financial statements. Consequently, expensive audit prices are required to compensate auditors' efforts.

\section{Summary and Conclusions}

This paper establishes the link between the introduction of guidance on FVM and the emergence of the GFC and the major implications of FVA practices on the audit profession. Through a comprehensive literature review, the paper contributes to FVA research by establishing the connection between management practices at Enron with a focus on FVA. The major findings of the paper relate to ambiguous practices of application of the initial FVA with questionable practices affecting business financial conditions. Demonstrated through the Enron case, the study provides a solid background for understanding of the ambiguated mark-to-model exploited opportunistically. The US credit crisis 2007 which bled into the GFC highlighted the critical impact of auditors' responsibilities to overcome the implications of the crisis and the FVA abuse by managers. Exposure to high risk and complexity in the auditing process translated into higher audit prices to ensure the creditability of the reported fair values and to eliminate the effect of agency problem. Another contribution of the paper is identifying two main streams of research in this area, identified as supporters and the opposers of this modern measurement basis: where FVA is based on exit prices in the market. The paper identifies that the challenge in fair value application emerges when there is no liquid market to fairly evaluate a firm's fair-valued assets. Without a financial exchange in an active market to determine fair values, fair-valued assets are usually estimated by using complex valuation models. Noticeably, although with improved disclosure requirements, financial institutions have turned to extensive usage of the model-based valuation method of FVA. This, in turn, has led to increased uncertainty among financial firms, investors, and regulators about the measurement of financial instruments. Although the current study presents a considerable discussion on the historical development of FVA, its relationship to the GFC and implications for the auditing profession, it suffers several limitations. The paper discusses the FVA concept from the auditing perspective; while ignoring its implications for other accounting practices. Future research is encouraged to investigate implications for accounting to assist standard setters, practitioners and academics in understanding, adoption and improvement of FVA practices. Empirical examinations on FVA and its implication for the accounting and auditing profession are greatly needed to fill the theoretical gap in current knowledge, such as audit and non-audit fees, financial disclosure and reporting quality.

\section{References}

Abdel-Khalik, A. R. (2002). Reforming corporate governance post Enron: Shareholders' Board of Trustees and the auditor. Journal of Accounting and Public Policy, 21(2), 97-103. https://doi.org/10.1016/S0278-4254(02)00040-6

Abdullatif, M. (2016). Auditing fair value estimates in developing countries: The case of Jordan. Asian Journal of Business and Accounting, 9(2), 101-40.

Alexeyeva, I., \& Svanström, T. (2015). The impact of the global financial crisis on audit and non-audit fees: Evidence from Sweden. Managerial auditing journal, 30(4-5), 302-323. https://doi.org/10.1108/MAJ-04-2014-1025

Allen, F., \& Carletti, E. (2008). Mark-to-market accounting and liquidity pricing. Journal of Accounting and Economics, 45(2-3), 358-378. https://doi.org/10.1016/j.jacceco.2007.02.005

Alqatamin, R. M. (2018). Audit committee effectiveness and company performance: Evidence from Jordan. Accounting and Finance Research, 7(2), 48. https://doi.org/10.5430/afr.v7n2p48

Amel-Zadeh, A., \& Meeks, G. (2015). Fair value and the great financial crisis The Routledge Companion to Financial Accounting Theory (pp. 217-236): Routledge. 
American Banking Association. (2008). Letter to SEC, September 23. www.sec.gov/ comments/4-573/4573-38.pdf.

An, Y., Davey, H., \& Eggleton, I. R. (2011). Towards a comprehensive theoretical framework for voluntary IC disclosure. Journal of Intellectual Capital, 12(4), 571-585. https://doi.org/10.1108/14691931111181733

André, P., Cazavan-Jeny, A., Dick, W., Richard, C., \& Walton, P. (2009). Fair value accounting and the banking crisis in 2008: Shooting the messenger. Accounting in Europe, 6(1), 3-24. https://doi.org/10.1080/17449480902896346

Archambault, J. J., \& Archambault, M. E. (2009). An analysis of social factors influencing the adoption of International Financial Reporting Standards. Journal for Global Business Advancement, 2(1-2), 38-53. https://doi.org/10.1504/JGBA.2009.023093

Badertscher, B. A., Burks, J. J., \& Easton, P. D. (2011). A convenient scapegoat: Fair value accounting by commercial banks during the financial crisis. The Accounting Review, 87(1), 59-90. https://doi.org/10.2308/accr-10166

Badia, M., Duro, M., Penalva, F., \& Ryan, S. (2017). Conditionally conservative fair value measurements. Journal of Accounting and Economics, 63(1), 75-98. https://doi.org/10.1016/j.jacceco.2016.10.006

Baker, C. R., \& Owsen, D. M. (2002). Increasing the role of auditing in corporate governance. Critical perspectives on accounting, 13(5-6), 783-795. https://doi.org/10.1006/cpac.2002.0566

Ball, R., (2016). IFRS-10 years later. Accounting and Business Research, 46(5), 545-71. https://doi.org/10.1080/00014788.2016.1182710

Ball, R., \& Brown, P. (1968). An Empirical Evaluation of Accounting Income Numbers." journal of Accounting Research. Autumn, 1, 59-78.

Barr, M. S. (2012). The financial crisis and the path of reform. Yale J. on Reg., 29, 91.

Barth, M. E., \& Landsman, W. R. (1995). Fundamental issues related to using fair value accounting for financial reporting. Accounting horizons, 9(4), 97.

Barth, M. E., \& Landsman, W. R. (2010). How did financial reporting contribute to the financial crisis? European Accounting Review, 19(3), 399-423. https://doi.org/10.1080/09638180.2010.498619

Bell, T. B., Causholli, M., \& Knechel, W. R. (2015). Audit firm tenure, non-audit services, and internal assessments of audit quality. Journal of accounting research, 53(3), 461-509. https://doi.org/10.1111/1475-679X.12078

Benston, G. J. (2006). Fair-value accounting: A cautionary tale from Enron. Journal of Accounting and Public Policy, 25(4), 465-484. https://doi.org/10.1016/j.jaccpubpol.2006.05.003

Bischof, J. (2009). The effects of IFRS 7 adoption on bank disclosure in Europe. Accounting in Europe, 6(2), 167-194. https://doi.org/10.1080/17449480903171988

Bolton, P., Scheinkman, J., \& Xiong, W. (2006). Executive compensation and short-termist behaviour in speculative markets. The Review of Economic Studies, 73(3), 577-610. https://doi.org/10.1111/j.1467-937X.2006.00388.x

Bonaci, C. G., Matis, D., \& Strouhal, J. (2010). Fair value and crisis: defense welcomed. Recent Advances in Management, Marketing, Finances, 71-75.

Boolaky, P. K., \& Soobaroyen, T. (2017). Adoption of International Standards on Auditing (ISA): Do institutional factors matter? International Journal of Auditing, 21(1), 59-81.https://doi.org/10.1111/ijau.12081

Bout, J.-L., Ter Hoeven, R., \& Langendijk, H. P. (2010). Fair-value-accounting, inactieve markten en procycliciteit. Maandblad voor Accountancy en Bedrijfseconomie, 84(1/2), 7-26. https://doi.org/10.5117/mab.84.10881

Bowen, R. M., Khan, U., \& Rajgopal, S. (2010). The economic consequences of relaxing fair value accounting and impairment rules on banks during the financial crisis of 2008-2009. Available at SSRN 1498912. https://doi.org/10.2139/ssrn.1498912

Bratten, B., Gaynor, L. M., McDaniel, L., Montague, N. R., \& Sierra, G. E. (2013). The audit of fair values and other estimates: The effects of underlying environmental, task, and auditor-specific factors. Auditing: A Journal of Practice \& Theory, 32(sp1), 7-44. https://doi.org/10.2308/ajpt-50316

Brinza, D. (2011). Historical cost and fair value within the context of financial crisis. Challenges of the Knowledge Society. Economy, 1497-1502.

Burton, T. L. (1971). Experiments in recreation research, 2, London: Allen and Unwin. 
Cahan, S. F., \& Sun, J. (2015). The effect of audit experience on audit fees and audit quality. Journal of Accounting, Auditing \& Finance, 30(1), 78-100. https://doi.org/10.1177/0148558X14544503

Cahan, S. F., \& Zhang, W. (2006). After Enron: Auditor conservatism and ex-Andersen clients. The Accounting Review, 81(1), 49-82. https://doi.org/10.2308/accr.2006.81.1.49

Carosio, G. (2008). La crisi finanziaria e il principio del Fair Value. Convegno di studi: crisi dei mercati finanziari e implicazioni, anche fiscali, sui bilanci delle imprese.

Cathey, J. M., Schauer, D., \& Schroeder, R. G. (2012). The impact of FSP FAS 157-4 on commercial banks. International Advances in Economic Research, 18(1), 15-27. https://doi.org/10.1007/s11294-011-9326-z

Chambers, R. J. (1966). ACCOUNTING EVALUATION AND ECONOMIC BEHAVIOR Prentice Hall. Englewood Cliffs, NJ.

Chen, H., Hua, S., Liu, Z., \& Zhang, M. (2019). Audit fees, perceived audit risk, and the financial crisis of 2008. Asian Review of Accounting. 27(1), 1321-7348. https://doi.org/10.1108/ARA-01-2017-0007

Clarke, T. (2007). International corporate governance: A comparative approach: Routledge. https://doi.org/10.4324/9780203300725

Coles, J. L., Daniel, N. D., \& Naveen, L. (2006). Managerial incentives and risk-taking. Journal of financial economics, 79(2), 431-468. https://doi.org/10.1016/j.jfineco.2004.09.004

de Jager, P. (2014). Liberal fair value accounting in banks: A South African case study. Australian Accounting Review, 24(2), 134-153. https://doi.org/10.1111/auar.12011

Demartini, C., \& Trucco, S. (2017). Audit Quality Integrated Reporting and Audit Quality: An Empirical Analysis in the European Setting, 37-58. Cham: Springer International Publishing. https://doi.org/10.1007/978-3-319-48826-4

Desai, H., Rajgopal, S., \& Yu, J. J. (2016). Were information intermediaries sensitive to the financial statement-based leading indicators of bank distress prior to the financial crisis? Contemporary Accounting Research, 33(2), 576-606. https://doi.org/10.1111/1911-3846.12161

Devalle, A. (2012). Value relevance of accounting data and financial crisis in Europe: an empirical analysis. International Journal of Accounting and Financial Reporting. 2(2), 201-217. https://doi.org/10.5296/ijafr.v2i2.2527

Dixon, J., \& Frolova, Y. (2013). Accounting for good governance: the fair value challenge. Corporate Governance: The international journal of business in society, 13(3), 318-331. https://doi.org/10.1108/CG-10-2011-0078

Doogar, R., Rowe, S. P., \& Sivadasan, P. (2015). Asleep at the wheel (again)? Bank audits during the lead-up to the financial crisis. Contemporary Accounting Research, 32(1), 358-391. https://doi.org/10.1111/1911-3846.12101

Duh, R.-R., Hsu, A. W.-h., \& Alves, P. A. P. (2012). The impact of IAS 39 on the risk-relevance of earnings volatility: Evidence from foreign banks cross-listed in the USA. Journal of Contemporary Accounting \& Economics, 8(1), 23-38. https://doi.org/10.1016/j.jcae.2012.03.002

Elder, R., Zhang, Y., Zhou, J., \& Zhou, N. (2009). Internal control weaknesses and client risk management. Journal of Accounting, Auditing \& Finance, 24(4), 543-579. https://doi.org/10.1177/0148558X0902400403

FASB. (1993). Statement of Financial Accounting Standards No. 115 Retrieved 24/2/2020 https://www.fasb.org/jsp/FASB/Document_C/DocumentPage?cid=1218220123971\&acceptedDisclaimer=true

FASB. (1998). Statement of Financial Accounting Standards No. 133 Retrieved 22//1/2020 https://www.fasb.org/jsp/FASB/Document_C/DocumentPage?cid=1218220124631\&acceptedDisclaimer=true

Flegm, E. H. (2005). Accounting at a Crossroad. The CPA Journal, 75(12), 16.

Freeman, W., Wells, P., \& Wyatt, A. (2017). Measurement Model or Asset Type: Evidence from an Evaluation of the Relevance of Financial Assets. Abacus, 53(2), 180-210. https://doi.org/10.1111/abac.12108

Gaynor, L. M., Kelton, A. S., Mercer, M., \& Yohn, T. L. (2016). Understanding the relation between financial reporting quality and audit quality. Auditing: A Journal of Practice \& Theory, 35(4), 1-22. https://doi.org/10.2308/ajpt-51453 
Gläser, J., \& Laudel, G. (2013). Life with and without coding: Two methods for early-stage data analysis in qualitative research aiming at causal explanations. Paper presented at the Forum Qualitative Sozialforschung/Forum: Qualitative Social Research.

Goh, B. W., Li, D., Ng, J., \& Yong, K. O. (2015). Market pricing of banks' fair value assets reported under SFAS 157 since the 2008 financial crisis. Journal of Accounting and Public Policy, 34(2), 129-145. https://doi.org/10.1016/j.jaccpubpol.2014.12.002

Graham, R., King, R., \& Bailes, J. (2000). The value relevance of accounting information during a financial crisis: Thailand and the 1997 decline in the value of the baht. Journal of International Financial Management \& Accounting, 11(2), 84-107. https://doi.org/10.1111/1467-646X.00057

Griffith, E. E., Hammersley, J. S., \& Kadous, K. (2015). Audits of complex estimates as verification of management numbers: How institutional pressures shape practice. Contemporary Accounting Research, 32(3), 833-863. https://doi.org/10.1111/1911-3846.12104

Groff, M., Trobec, D., \& Igličar, A. (2017). Audit fees and the salience of financial crisis: evidence from Slovenia. Economic research-Ekonomska istraživanja, 30(1), 922-938. https://doi.org/10.1080/1331677X.2017.1311233

Gwilliam, D., \& Jackson, R. H. (2008). Fair value in financial reporting: Problems and pitfalls in practice. Paper presented at the Accounting Forum. https://doi.org/10.1016/j.accfor.2008.01.003

Hackenbrack, K., \& Knechel, W. R. (1997). Resource allocation decisions in audit engagements. Contemporary Accounting Research, 14(3), 481-499. https://doi.org/10.1111/j.1911-3846.1997.tb00537.x

Haldeman, R. (2006). Fact, fiction, and fair value accounting at Enron. CPA JOURNAL, 76(11), 14.

Haswell, S., \& Evans, E. (2018). Enron, fair value accounting, and financial crises: a concise history. Accounting, Auditing \& Accountability Journal, 31(1), 0951-3574. https://doi.org/10.1108/AAAJ-04-2016-2525

Haswell, S., \& Langfield-Smith, I. (2008). Fifty-Seven Serious Defects in 'Australian'IFRS. Australian Accounting Review, 18(1), 46-62. https://doi.org/10.1111/j.1835-2561.2008.0006.x

Healy, P. M., \& Palepu, K. G. (2001). Information asymmetry, corporate disclosure, and the capital markets: A review of the empirical disclosure literature. Journal of Accounting and Economics, 31(1-3), 405-440. https://doi.org/10.1016/S0165-4101(01)00018-0

Heaton, J. C., Lucas, D., \& McDonald, R. L. (2010). Is mark-to-market accounting destabilizing? Analysis and implications for policy. Journal of Monetary Economics, 57(1), 64-75. https://doi.org/10.1016/j.jmoneco.2009.11.005

Hodge, F., \& Pronk, M. (2006). The impact of expertise and investment familiarity on investors' use of online financial report information. Journal of Accounting, Auditing \& Finance, 21(3), 267-292. https://doi.org/10.1177/0148558X0602100304

Holm, C., \& Zaman, M. (2012). Regulating audit quality: Restoring trust and legitimacy. Paper presented at the Accounting forum. https://doi.org/10.1016/j.accfor.2011.11.004

Hopwood, A. G. (2009). The economic crisis and accounting: Implications for the research community. Accounting, organizations and society, 34(6-7), 797-802. https://doi.org/10.1016/j.aos.2009.07.004

https://doi.org/10.1080/10941661003687431

Humphrey, C., Loft, A., \& Woods, M. (2009). The global audit profession and the international financial architecture: Understanding regulatory relationships at a time of financial crisis. Accounting, organizations and society, 34(6-7), 810-825. https://doi.org/10.1016/j.aos.2009.06.003

IAASB. (2004). Auditing Fair Value Measurements and Disclsoures. Retrieved from https://www.ifac.org/system/files/downloads/2008_Auditing_Handbook_A155_ISA_545.pdf

IAASB. (2008). Staff Audit Practice Alert - Challenges in Auditing Fair Value Accounting Estimates in the Current Market Environment. Retrieved from https://www.iaasb.org/publications/staff-audit-practice-alert-challenges-auditing-fair-value-accounting-estimate s-current-market-0

IAASB. (2009). Auditing Accounting Estimates, Including Fair Value Accounting Estimates, and Related Disclsoures. $\begin{array}{llllll}\text { Retrieved 23/3/2020, from } & \text { IASSB } & \text { Handbook } & \text { ISA } & 540\end{array}$ https://www.ifac.org/system/files/downloads/a028-2010-iaasb-handbook-isa-540.pdf 
IAS Plus. (2019). IAS 39-Financial Instruments: Recognition and Measurement. Retrieved from https://www.iasplus.com/en/standards/ias/ias39

IAS Plus. (2020). IFRS 13-Fair Value Measurement. Retrieved from https://www.iasplus.com/en/standards/ifrs/ifrs13

IFRS Foundation. (2020a). Expert Advisory Panel-Fair Value Measurement. Retrieved from https://www.ifrs.org/groups/expert-advisory-panel-fair-value-measurement/

IFRS Foundation. (2020b). Use of IFRS Standards around the world. Retrieved from https://cdn.ifrs.org/-/media/feature/around-the-world/adoption/use-of-ifrs-around-the-world-overview-sept-2018 .pdf?la=en

Johnson, E. N., Walker, K. B., \& Westergaard, E. (1995). Supplier concentration and pricing of audit services in New Zealand. Auditing, 14(2), 74.

Khlif, H., \& Achek, I. (2016). IFRS adoption and auditing: a review. Asian Review of Accounting. 24(3), 338-61. https://doi.org/10.1108/ARA-12-2014-0126

Kikhia, H. Y. (2015). Determinants of audit fees: evidence from Jordan', Accounting and finance Research. 4(1), 42-53. https://doi.org/10.5430/afr.v4n1p42

Kolev, K. S. (2008). Do investors perceive marking-to-model as marking-to-myth? Early evidence from FAS 157 disclosure. Early Evidence from FAS, 157. https://doi.org/10.2139/ssrn.1336368

Kothari, S. (2001). Capital markets research in accounting. Journal of Accounting and Economics, 31(1-3), 105-231. https://doi.org/10.1016/S0165-4101(01)00030-1

Krippner, G. R. (2005). The financialization of the American economy. Socio-economic review, 3(2), 173-208. https://doi.org/10.1093/SER/mwi008

Krishnan, G. V., \& Zhang, Y. (2014). Is there a relation between audit fee cuts during the global financial crisis and banks' financial reporting quality? Journal of Accounting and Public Policy, 33(3), 279-300. https://doi.org/10.1016/j.jaccpubpol.2014.02.004

Lachmann, M., Stefani, U., \& Wöhrmann, A. (2015). Fair value accounting for liabilities: Presentation format of credit risk changes and individual information processing. Accounting, organizations and society, 41, 21-38. https://doi.org/10.1016/j.aos.2014.08.001

Laux, C. (2012). Financial instruments, financial reporting, and financial stability. Accounting and Business Research, 42(3), 239-260. https://doi.org/10.1080/00014788.2012.681857

Laux, C., \& Leuz, C. (2009). The crisis of fair-value accounting: Making sense of the recent debate. Accounting, organizations and society, 34(6-7), 826-834. https://doi.org/10.1016/j.aos.2009.04.003

Laux, C., \& Leuz, C. (2010). Did fair-value accounting contribute to the financial crisis? Journal of economic perspectives, 24(1), 93-118. https://doi.org/10.1257/jep.24.1.93

Leuz, C. (2010). Different approaches to corporate reporting regulation: How jurisdictions differ and why. Accounting and Business Research, 40(3), 229-256. https://doi.org/10.1080/00014788.2010.9663398

MacKenzie, D. (2006). Is economics performative? Option theory and the construction of derivatives markets. Journal of the history of economic thought, 28(1), 29-55. https://doi.org/10.1080/10427710500509722

Magnan, M. L. (2009). Fair value accounting and the financial crisis: messenger or contributor? Accounting perspectives, 8(3), 189-213. https://doi.org/10.1506/ap.8.3.1

Mala, R., \& Chand, P. (2012). Effect of the global financial crisis on accounting convergence. Accounting \& Finance, 52(1), 21-46. https://doi.org/10.1111/j.1467-629X.2011.00418.x

Matherat, S. (2008). Fair value accounting and financial stability: challenges and dynamics. Financial Stability Review, 12, 53-64.

Mattingly, J. E., Harrast, S. A., \& Olsen, L. (2009). Governance implications of the effects of stakeholder management on financial reporting. Corporate Governance: The international journal of business in society. https://doi.org/10.1108/14720700910964334

McCreevy, C. (2008). Latest developments on policy response to financial turmoil. European Parliament's Committee on Economic and Monetary Affairs. Najdeno, 15, 1-6. 
McLean, B., \& Elkind, P. (2013). The smartest guys in the room: The amazing rise and scandalous fall of Enron: Penguin.

Menicucci, E., \& Paolucci, G. (2016). Fair value accounting and the financial crisis: a literature-based analysis. Journal of Financial Reporting and Accounting, 14(1), 49-71. https://doi.org/10.1108/JFRA-05-2014-0049

Nguyen, L.-U. (2019). The (un) suitability of fair-value accounting in emerging economies: the case of Vietnam. Journal of Accounting \& Organizational Change. 15(2), 170-197. https://doi.org/10.1108/JAOC-03-2018-0032

Nobes, C. W. (2005). Rules-based standards and the lack of principles in accounting. Accounting horizons, 19(1), 25-34. https://doi.org/10.2308/acch.2005.19.1.25

Novoa, A., Sole, J., \& Scarlata, J. G. (2009). Procyclicality and fair value accounting, International Monetary Fund, 9.

Partnoy, F. (2003). Infectious Greed: How deceit and risk corrupted the Financial Markets: Times Books New York.

PCAOB. (2020). Auditing Accounting Estimates, Including Fair Value Measurements. Retrieved from https://pcaobus.org/Standards/research-standard-setting-projects/Pages/auditing-accounting-estimates-fair-value .aspx

Penman, S. H. (2007). Financial reporting quality: is fair value a plus or a minus? Accounting and Business Research, 37(sup1), 33-44. https://doi.org/10.1080/00014788.2007.9730083

Perry, J., \& Nöelke, A. (2005). International accounting standard setting: A network approach. Business and Politics, 7(3), 1-32. https://doi.org/10.2202/1469-3569.1136

Perry, J., \& Nölke, A. (2006). The political economy of international accounting standards. Review of international political economy, 13(4), 559-586. https://doi.org/10.1080/09692290600839790

Plantin, G., \& Tirole, J. (2018). Marking to market versus taking to market. American Economic Review, 108(8), 2246-2276. https://doi.org/10.1257/aer.20161749

Plantin, G., Sapra, H., \& Shin, H. S. (2008). Marking-to-market: panacea or Pandora's box? Journal of accounting research, 46(2), 435-460. https://doi.org/10.1111/j.1475-679X.2008.00281.x

Power, M. (2010). Fair value accounting, financial economics and the transformation of reliability. Accounting and Business Research, 40(3), 197-210. https://doi.org/10.1080/00014788.2010.9663394

Pozen, R. C. (2009). Is it fair to blame fair value accounting for the financial crisis? Harvard Business Review. 87(11).

Procházka, D. (2011). The role of fair value measurement in the recent financial crunch. Economics, Management, and Financial Markets, 6(1), 989-1001. https://doi.org/10.18267/j.pep.388

Revsine, L. (2002). Enron: sad but inevitable. Journal of Accounting and Public Policy, 21(2), 137-137. https://doi.org/10.1016/S0278-4254(02)00044-3

Roberts, J., \& Jones, M. (2009). Accounting for self interest in the credit crisis. Accounting, organizations and society, 34(6-7), 856-867. https://doi.org/10.1016/j.aos.2009.03.004

Ruddock, C. Taylor, S. J., \& Taylor, S. L., (2006). Nonaudit services and earnings conservatism: Is auditor independence impaired?. Contemporary Accounting Research, 23(3), 701-46. https://doi.org/10.1506/6AE8-75YW-8NVW-V8GK

Rummell, N. (2008). Fair-value rules get more blame for crunch. Financial Week, 24.

Ryan, S. G. (2008). Accounting in and for the subprime crisis. The Accounting Review, 83(6), 1605-1638. https://doi.org/10.2308/accr.2008.83.6.1605

Samaha, K., \& Khlif, H. (2016). Adoption of and compliance with IFRS in developing countries: A synthesis of theories and directions for future research. Journal of Accounting in Emerging Economies, 6(1), 33-49. https://doi.org/10.1108/JAEE-02-2013-0011

Sangchan, P., Habib, A., Jiang, H., \& Bhuiyan, M. B. U. (2020). Fair Value Exposure, Changes in Fair Value and Audit Fees: Evidence from the Australian Real Estate Industry. Australian Accounting Review. 30(93), 123-143. https://doi.org/10.1111/auar.12299

Saunders, M., Lewis, P., \& Thornhill, A. (2009). Research Methods for Business Students. Pears on Education Limited, England. 
Schultz, S. M., \& Hollister, J. (2003). Lobbying FASB on accounting for investments. Journal of Applied Business Research (JABR), 19(2). https://doi.org/10.19030/jabr.v19i2.2163

Shaffer, S. (2010). Fair value accounting: villain or innocent victim-exploring the links between fair value accounting, bank regulatory capital and the recent financial crisis. FRB of Boston Quantitative Analysis Unit Working Paper(10-01). https://doi.org/10.2139/ssrn.1543210

Shaw, K. W. (2003). Corporate disclosure quality, earnings smoothing, and earnings' timeliness. Journal of Business Research, 56(12), 1043-1050. https://doi.org/10.1016/S0148-2963(01)00328-9

Sikka, P. (2009). Financial crisis and the silence of the auditors. Accounting, organizations and society, 34(6-7), 868-873. https://doi.org/10.1016/j.aos.2009.01.004

Simnett, R., Carson, E., \& Vanstraelen, A. (2016). International archival auditing and assurance research: Trends, methodological issues, and opportunities. Auditing: A Journal of Practice \& Theory, 35(3), 1-32. https://doi.org/10.2308/ajpt-51377

Smith-Lacroix, J.-H., Durocher, S., \& Gendron, Y. (2012). The erosion of jurisdiction: Auditing in a market value accounting regime. Critical perspectives on accounting, 23(1), 36-53. https://doi.org/10.1016/j.cpa.2011.09.002

Song, C. J., Thomas, W. B., \& Yi, H. (2010). Value relevance of FAS No. 157 fair value hierarchy information and the impact of corporate governance mechanisms. The Accounting Review, 85(4), 1375-1410. https://doi.org/10.2308/accr.2010.85.4.1375

Song, H., Lin, S., Zhang, X., \& Gao, Z. (2010). Global financial/economic crisis and tourist arrival forecasts for Hong Kong. Asia Pacific journal of tourism research, 15(2), 223-242. https://doi.org/10.1080/10941661003687431

Song, X. (2015). Value relevance of fair values-Empirical evidence of the impact of market volatility. Accounting perspectives, 14(2), 91-116. https://doi.org/10.1111/1911-3838.12045

Sonu, C. H., Ahn, H., \& Choi, A. (2017). Audit fee pressure and audit risk: evidence from the financial crisis of 2008. $\begin{array}{lllll}\text { Asia-Pacific journal of accounting \& economics, } & 24(1-2), & 127-144 .\end{array}$ https://doi.org/10.1080/16081625.2016.1208574

Sterling, R. R. (1967). Conservatism: The fundamental principle of valuation in traditional accounting. Abacus, 3(2), 109-132. https://doi.org/10.1111/j.1467-6281.1967.tb00375.x

Sterling, R. R. (1970). On theory construction and verification. The Accounting Review, 45(3), 444-457.

Trussel, J. M., \& Rose, L. C. (2009). Fair value accounting and the current financial crisis. The CPA Journal, 79(6), 26.

Uzma, S. H. (2016). Cost-benefit analysis of IFRS adoption: developed and emerging countries. Journal of Financial Reporting and Accounting, 14(2), 198-229. https://doi.org/10.1108/JFRA-01-2015-0019

Veron, N. (2008). Fair value accounting is the wrong scapegoat for this crisis. Accounting in Europe, 5(2), 63-69. https://doi.org/10.1080/17449480802510542

Wallace, M. (2008). Is fair-value accounting responsible for the financial crisis? Is this a case of shooting the messenger? Bank Accounting \& Finance, 22(1), 9-21.

Wallison, P. J. (2008). Fair value accounting: A critique. Financial Services Outlook, 1-8. https://doi.org/10.1787/budget-9-5ks72wvj5lmw

Watts, R. L. (2006). What has the invisible hand achieved?. Accounting and Business Research, 36(sup1), 51-61. https://doi.org/10.1080/00014788.2006.9730046

Wells, D. (2005). Best practice in the regulation of international labor standards: Lessons of the US-Cambodia textile agreement. Comp. Lab. L. \& Pol'y. J., 27, 357.

Whalen, C. (2008). Understanding the credit crunch as a Minsky moment. Challenge, 51(1), 91-109. https://doi.org/10.2753/0577-5132510106

Whittington, G. (2015). Measurement in financial reporting: half a century of research and practice. Abacus, 51(4), 549-571. https://doi.org/10.1111/abac.12061

Woods, M., Humphrey, C., Dowd, K., \& Liu, Y.-L. (2009). Crunch time for bank audits? Questions of practice and the scope for dialogue. Managerial auditing journal, 24(2), 114-134. https://doi.org/10.1108/02686900910924545

Xu, Y., Carson, E., Fargher, N., \& Jiang, L. (2013). Responses by Australian auditors to the global financial crisis. Accounting \& Finance, 53(1), 301-338. https://doi.org/10.1111/j.1467-629X.2011.00459.x 
Yao, D., Percy, M., Stewart, J., \& Hu, F. (2018). Determinants of discretionary fair value measurements: the case of Level 3 assets in the banking sector. Accounting \& Finance, 58(2), 561-597. https://doi.org/10.1111/acfi.12225

Zeff, S. A. (2007). Some obstacles to global financial reporting comparability and convergence at a high level of quality. The British accounting review, 39(4), 290-302. https://doi.org/10.1016/j.bar.2007.08.001

Zeghal, D., \& Mhedhbi, K. (2006). An analysis of the factors affecting the adoption of international accounting standards by developing countries. The International Journal of Accounting, 41(4), 373-386. https://doi.org/10.1016/j.intacc.2006.09.009

Zhang, T., \& Huang, J. (2013). The risk premium of audit fee: Evidence from the 2008 financial crisis. China Journal of Accounting Studies, 1(1), 47-61. https://doi.org/10.1080/21697221.2013.781766 


\section{Appendix A}

Table 1. Summary of FVA and Related Auditing Standards Development Timeline

\begin{tabular}{lll}
\hline Date & Development & Comments \\
\hline $\begin{array}{l}\text { December 1975 } \\
\text { October 1984 }\end{array}$ & FAS12: Accounting for Marketable Securities issued by FASB & \\
March 1986 & Exposure Draft E26 Accounting for Investments & \\
& IAS 25 Accounting for Investments issued by FASB & $\begin{array}{l}\text { Operative for financial } \\
\text { statements covering periods } \\
\text { beginning on or after } 1 \\
\text { January 1987 }\end{array}$
\end{tabular}

September 1991

May 1993

January 1994

June 1995

January 1996

March 1997

June 1998

June 1998

December 1998

IAS 32 was revised

by IAS 39,

effective 1 January

2001

December 1998

April 2000

October 2000

Limited revisions to IAS 39

October 2002

December 2003

March 2004

December 2004 40 Investment Property
Exposure Draft E40 Financial Instruments

FAS 115: Accounting for Certain Investments

in Debt and Equity Securities issued by FASB

E40 was modified and re-exposed as Exposure Draft

E48 Financial Instruments

The disclosure and presentation portion of E48 was adopted as IAS 32: Financial Instruments: Presentation

Effective date of IAS 32 (1995) by IASB

Discussion Paper Accounting for Financial Assets and Financial Liabilities issued

FAS 133: Accounting for Derivative Instruments

and Hedging Activities

Exposure Draft E62 Financial Instruments: Recognition and Measurement issued

Comment deadline 30 September 1998
IAS 39 Financial Instruments: Recognition and Effective date 1 January Measurement (1998) issued by IASB 2001

Withdrawal of IAS 25 following the approval of IAS

Effective for financial statements covering periods beginning on or after 1 January 2001

Effective date 1 January 2001

Convergence Project between the FASB and the IASB

IAS 39 Financial Instruments: Recognition and Measurement (2004) issued by IASB

IAS 39 revised to reflect macro hedging
Effective for annual periods beginning on or after 1 January 2005

Effective for annual periods beginning on or after 1 January 2005

Amendment issued to IAS 39 for transition and initial recognition of profit or loss 


$\begin{array}{llll}\text { December 2004 ISA-545, "Auditing Fair Value Measurements and } \begin{array}{l}\text { Effective for audits of } \\ \text { financial statements for } \\ \text { periods } \\ \text { Disclosures" issued by IAASB. }\end{array} & \begin{array}{l}\text { beginning on or after } \\ \text { December 15, 2004 }\end{array}\end{array}$

September 2005

April 2005

June 2005

August 2005

September 2006

January 2007

December 2007

November 2007

December 2007

February 2008

May 2008

July 2008

October 2008

October 2008

Late-2008

March 2009

April 2009
Fair Value Accounting added to the active agenda

Amendment issued to IAS 39 for cash flow hedges of forecast intragroup transactions

Amendment to IAS 39 for fair value option

Amendment to IAS 39 for financial guarantee contracts

SFAS 157 Fair Value Measurements issued by FASB

Effective version of IFRS 7: Financial Instruments: Disclosures issued by IASB through IFRS

Revised FAS141: Business Combinations released by FASB

FAS159 The Fair Value Option become effective

Staff Audit Practice Alert No. 2 released by PCAOB

ISA 540-Auditing Accounting Estimates, Including FVA Estimates, and Related Disclosures ISA 540 issued by IAASB.

IAS 39 amended for Annual Improvements to IFRSs 2007

Amendment to IAS 39 for eligible hedged items

IASB publishes Report of its Expert Advisory Panel on Valuing Financial Instruments in Inactive Markets

Amendment to IAS 39 and IFRS 7 for reclassifications of financial assets

Fair Value blamed for causing the economic downturn

Amendment to IAS 39 for embedded derivatives on reclassifications of financial assets

KPMG sued over issuing an adverse opinion for New Century Financial, as a result of not being able to effectively test the provided $\mathrm{FV}$ estimates

FASB issues FSP FAS 157 to provide reassurance and guidance as to how to apply FV measurement

PCAOB issued Staff Audit Practice Alert No. 4, which presents varying methods for auditors to test FV estimates of
Effective for annual periods beginning on or after 1 January 2006

Effective for annual periods beginning on or after 1 January 2006

Effective for annual periods beginning on or after 1 January 2006

Effective for annual periods beginning on or after 1 January 2009

Effective for annual periods beginning on or after 1 July 2009

Effective 1 July 2008

Effective for annual periods beginning on or after 1 July 2009 
management during

financial statement audits

April 2009

IAS 39 amended for Annual Improvements to IFRSs 2009

May 2009

November 2009

December 2009

Late-2009

June 2010

August 2010

October 2010

May 2011

May 2011

December 2012

June 2013

November 2013

July 2014

December 2018
Exposure Draft ED/2009/5 Fair Value Measurement published

IFRS 9 Financial Instruments issued, replacing the classification and measurement of financial assets provisions of IAS 39

IASB requests examples and case studies from emerging and transition economies

The FV debate continues, but it appears that the Convergence Project will continue to progress forward

Exposure Draft ED/2010/7 Measurement Uncertainty Analysis Disclosure for Fair Value Measurements published

Staff Draft of IFRS on Fair Value Measurement published

IFRS 9 Financial Instruments reissued, incorporating new requirements on accounting for financial liabilities and carrying over from IAS 39 the requirements for derecognition of financial assets and financial liabilities

ASC 820 Fair Value Measurement issued by FASB

IFRS 13 Fair Value Measurements issued by IASB through IFRS

Educational guidance first chapter Measuring the fair value of unquoted equity instruments within the scope of IFRS 9 Financial Instruments published

Amended by Novation of Derivatives and Continuation of Hedge Accounting

IFRS 9 Financial Instruments (Hedge Accounting and amendments to IFRS 9, IFRS 7 and IAS 39) issued, permitting an entity to elect to continue to apply the hedge accounting requirements in IAS 39 for a fair value hedge of the interest rate exposure of a portion of a portfolio of financial assets or financial liabilities when IFRS 9 is applied, and to extend the fair value option to certain contracts that meet the 'own use' scope exception

IFRS 9 Financial Instruments issued by IASB through IFRS, replacing IAS 39 requirements for classification and measurement, impairment, hedge accounting and derecognition

AS 2501: Auditing Accounting Estimates, Including Fair Value Measurements, and related amendments issued by $\mathrm{PCAOB}$
Effective for annual periods beginning on or after 1 January 2010

Comment deadline 28 September 2009

Original effective date 1 January 2013, later deferred and subsequently removed

Deadline 31 January 2010

Comment deadline 7 September 2010

Original effective date 1 January 2013, later deferred and subsequently removed

Effective for annual periods beginning on or after 1 January 2013

Effective for annual periods beginning on or after 1 January $2014 \quad$ (earlier application permitted)

Applies when IFRS 9 is applied

Effective for annual periods beginning on or after 1 January 2018

Effective for annual periods beginning on or after 2019

Developed by the researchers (IAS Plus 2019; IAASB 2009; IAASB 2004; PCAOB 2020) 